\title{
Legal Pluralism Approaches and Customary Land Rights Disputes on Indigenous Law Communities of Sentani Papua
}

\author{
Frans Reumi \\ Senior Lecturer At Faculty of law, University of Cendrawasih, Papua - Indonesia
}

\begin{abstract}
The aim is to understand and analyze the approach of legal pluralism in the resolution of land rights disputes. The methodology of the research is normative and empirical juridical methods. The data are collected through primary and secondary legal materials. It conducts als interviews to relevant rerspondents. The data then analyze qualitative. The results of the research show that the existence of a diversity of legal systems (state law, customary law, religious law, and other customs) affects the object of customary land rights disputes in the customary law community Sentani Jayapura Regency Papua Province. The reasons for the choice of Sentani customary law community are: 1) sense of social justice because of the balance values based on the kinship legal system; 2) low cost and / or even no fees; 3) determined and fast trial is not convoluted; and 4) a sense of collective / social justice based on "cosmic" values not individual justice. The customary land rights disputes itself is determined by: a) patterns of ownership and control of communal customary land to be individual; b) land value from social value to economic value; c) tenuous family relations; d) differences in perceptions between the customary law community and the government of the concept of customary land rights; and e) the source of land disputes due to the history of origin, the system of land ownership and customary land boundaries is unclear because of the regional expansion, administrative boundaries and cultural boundaries at the level Yo kla, village/ Yo Khani, clan-owned lands/Khani Khoselo, service land/Khani Memokhoi, private land/Umbai Khani; f) inherited land, war land, magical land, service land, marital land, forfeit land; and g) historical land, Dutch land, leadership land, cultural customary land boundary to administration, land compensation. The form of dispute over customary land rights, such as 1) the concept of the legal substance of the object of the dispute, 2) the legal structure of the institution that has the function to resolve land tenure and land ownership disputes or land boundaries, 3) the mechanism or procedure in the court and other institutions that can resolve land tenure disputes, and 4) legal culture, legal substance and legal structure. Thus, the form of settlement of customary land disputes over the land of the Sentani customary community through two channels, namely: formal justice (litigation) and non-formal justice (non litigation). The reality is that the indigenous law communities of Sentani are more inclined to the non-litigation mechanism according to reasons of choice of law and sense of justice.
\end{abstract}

Keywords: Legal Pluralism, Land Disputes, Customary Law Communities.

DOI: $10.7176 / \mathrm{JLPG} / 91-07$

Publication date: November $30^{\text {th }} 2019$

\section{Introduction}

Since the early 1960s the development of legal pluralism (legal pluralism) has been present as an important theme in the study of the legal system in the independent countries of Africa and Asia with European legal systems in historical and political contexts as a form of legal acculturation into their respective legal systems. each of these independent countries. This means that due to legal acculturation, independent countries of Africa and Asia become adherents of the European legal system, which is more adherent to state law, in its development being influenced by other habits such as customs, morals, beliefs, ethnicity and clen in the way of judging according to the system law. ${ }^{1}$ For example: state law, customary law and religious law can be referred to as the living law in the legal history of each independent country.

Indonesia has a long history of legal politics as an adherent to the civil law system (Continental Europe) and became an independent country since August 17, 1945. The social reality (society) of Indonesia which is pluralistic in culture, customs, religion, and customary law, lives side by side civil law system (Continental Europe) is still alive, guided and operated in a free way outside the country's legal system as a legal system, which lives side by side, interacts with and complements one another. The basic thing was the existence of legal pluralism that could be portrayed by the Indonesian people at that time, namely the existence of juridical division of groups in the beginning of legal pluralism reflected in Article 163 I.S. (Indische Staatregeling) namely: For Europeans, European Law applied, For Foreigners, the state law applied, For Bumiputera Customary Law applied. This means that the division of groups referred to shows more than one legal system is used in terms of the regulation of population groups at the time, and indirectly shows the situation of legal pluralism in the legal field.

${ }^{1}$ Werner Menski, Perbandingan Hukum Dalam Konteks Global Sistem Eropa, Asia, dan Afrika (Comparative Law In Global Context). Penerbit Nusamedia, Bandung, Tahun 2012, p. 113 
The validity of the legal system both outside the state legal system and in the state legal system has different sources and developments in the political history of law, in the form of ideal rules as material law and procedural rules of formal law, and "has a unique way of perceiving reality, social (community) and gives meaning to a social reality ${ }^{1}$." Then in certain aspects legal pluralism is contradictory and / or contrary to ideal and procedural rules, legal centralism (legal centralism) which falsifies that the country's legal system monopolizes the political system of law and negates other forms of legal system that exist in the life of Indonesian people pluralistic. The existence of a state law review is a uniform law for all certain legal societies, so that it is governed by a single legal system of political organization, namely the state, and for other legal systems it can only live if it is recognized by the political system of state law as limited to recognition. ${ }^{2}$ Whereas the regulation is influenced by the political system of the state law, namely the legal system of civi law (Continental Europe) which endorses the codification of the law, the unification of the law and legal viction as the power force applicable to the state of its adherents for positive legal unity. Directly or not, the development of legal pluralism can be interpreted in two understandings from the normative aspect, i.e: first, legal pluralism as a fact of legal diversity in a particular society. Therefore, plural means there are many and all show their existence in their respective legal systems, when the parties seeking justice make the choice of law according to their expectations. The field of legal pluralism that is often found are: customary law, national law, religious law, international law all exist and interact with each other to fill and complement. According to John Griffith ${ }^{3}$ states that "Legal pluralism is the fact, legal centralism is just a myth, en ideal, an illusion. Second, legal pluralism as an "approach in legal research" as the fourth approach after legal philosophy, legal positivism and socio-legal approach. This becomes a reference to Werner Menski's income, legal pluralism as an approach in legal research that links state law (positivism), living law (socio-legal approach) and natural law (moral, ethic and religion), "growing in countries independent of Africa and Asia. ${ }^{4}$ Monofacet is a law that is interpreted in one face or can be called legal centralism. Legal centralism stems from the philosophy of positisvism which uses approaches in the natural sciences in solving all problems. The law only is like laws and regulations. ${ }^{5}$ Multifacet is that the law is not only in the form of laws and regulations, the conception of legal pluralism appears as a rebuttal of legal centralism that state law is the only guide and guideline for behavior. Aside from being a legal regulation, the face of the law can be in the form of: judges' decisions, truth and justice values, patterned behavior and the meaning behind behavior. There are at least five legal faces as mentioned above. ${ }^{6}$

If it is reduced normatively or empirically, there is a situation of legal pluralism coloring the legal field, meaning there is a rejection of the dominance of the state law against various other legal rules (legal systems) which in reality there are many laws in various societies (residents) of the state and customary law communities or tribes a certain nation, as the seventh world community towards a plural society that does not recognize cultural, economic, political, and legal boundaries as a state boundary in entering the 21 st century. This means that the dominance of the legal system will usually have an impact on changing the tenure system of customary law communities and varies from one customary law community to another customary law community based on the lifestyle of the customary law community. Because customary law communities are not always static but are always dynamically following the changing times.

Legal pluralism is basically a process of interaction between different legal systems in the social (social) order of life in order to achieve legal objectives namely legal certainty, legal usefulness, and justice. Interpreting the process of interaction of various legal systems mainly takes place, between state law and. folk law, although there can be a reciprocal relationship of complementarity and complementarity. Giving rise to potential disputes between legal systems, especially between state law and folk law. The incorporation or recognition and protection of a legal system by other laws, or the effect of certain laws on law, ${ }^{5}$ is highly determined to what extent the legal system is used by indigenous and tribal peoples in dispute resolution to achieve a sense of legal certainty and justice based on the legal culture system of the legal community local custom.

Understanding the situation of legal pluralism, there is a tendency that in various countries including Indonesia the study of legal pluralism does receive important attention to disputes cases arising from the beginning to the end of its settlement colored in interactions between state law and folk law, which are more dominated by state law than folk law, especially in the independent countries of the former colonial colony that

\footnotetext{
${ }^{1}$ Slaats, Herman \& Karen Portier, Traditional Decision-Making and Law. Institutions and Processes in An Indonesian Context. Terutama Bagian "Introduction. Gadjah Mada University Press, Yogyakartya, 1992.

${ }^{2}$ Yando Zakaria dan Djaka Soehendra, Pengaturan Hukum Adat Tanah Dalam Perundang-Undangan Nasional dan Rasa Keadilan, (Makalah) at the National Land Pluralism Seminar in Indonesia, held by YLBHI, Jakarta, 7 September 1994.

${ }^{3}$ John Griffith, “What is Legal Pluralism”, Journal of Legal Pluralism, 1986, p. 24.

${ }^{4}$ Werner Menski, Perbandingan Hukum Dalam Konteks Global Sistem Eropa, Asia, dan Afrika (Comparative Law in Global Context). Penerbit Nusamedia, Bandung, 2012, pg, 113, in Suteksi and Galang Taufani, Metodologi Penelitian Hukum, 2018, Op Cit, pp. 31-32.

${ }_{5}^{5}$ Suteksi and Galang Taufani, Metologi Penelitian Hukum (Filsafat, Teori dan Filsafat). Rajawali Pers Depok

${ }^{6}$ Ibid.

5 Allot, Anthony \& Gordon R. Woodman, "Introduction", in People's Law and State Law, Anthony \& Gordon R. Woodman (eds). Foris Publications, Dordrect-Holland, 1985.
} 
still adheres to its abandoned legal system. For example, the former Dutch colony with the civi law system prioritizing codification and unification of law, is now an Indonesian legal system and at the same time a source of material law (KUHP) and Civil Code and formal law (KUHAP and KUHAPerdata) are used in the settlement of disputes and / or criminal acts according to levels Indonesian justice system. The diversity of the legal system was responded to as a symptom of legal pluralism, in which the themes of dispute resolution or criminal acts that initially focused on the study of traditional procedures, then began to be examined by looking at the relationships of traditional, neotraditional institutions and state legal institutions, because at that time the entry of the European legal system in the colonies or former colonies is usually the legal system in the independent country concerned. Efforts to understand legal pluralism are the processes of interaction between different legal systems in the order of social life. The process of interaction mainly occurs between state law and folk law, although there can be a relationship or contradiction, causing conflicts between the legal system, especially between state law and folk law. Incorporation or recognition of a legal system by other laws, or the effect of certain laws on law. ${ }^{1}$ In connection with the situation of legal pluralism, there is a tendency that in various countries including Indonesia the study of legal pluralism (legal pluralism) does indeed receive important attention to cases of disputes arising from the beginning to the end of its settlement colored by interactions between state law and folk law, which are more dominated by state law rather than folk law, especially in the independent states of the former colonial colony. For example in the mid-14th century the diversity of the legal system that existed in societies in the world was responded to as a symptom of the development of legal evolution, then in the 20th century the diversity of the legal system was responded to as a symptom of legal pluralism since the 1960s examine the themes of traditional dispute resolution procedures, by looking at the relations of traditional, neotraditional institutions and state legal institutions, because at that time the entry of European legal systems in the colonies or former colonies. ${ }^{2}$

Efforts to legal pluralism approach, as a method for studying the themes of resolving customary land disputes over customary community land are colored by various interacting legal systems confronted with a particular dispute object. For example, land disputes between communities, customary law communities and the government, the private sector, companies for development, business/personal interests, the parties to the dispute must choose which legal system is appropriate to resolve disputes faced by indigenous peoples.

In the history of Indonesian customary law by van Vollenhoven identified nineteen (19) customary law territories in customary law communities in Indonesia as the work of an ethnographer producing a customary law report that reflects the ethnographic model of law, and the 14th customary law area in the Irianese customary law community ( Papua) in his book Adatrecht I. With the identification of the ethnography of the law only simply shows that the customary law community of Papua has cultural differences and customary law with a distribution based on cultural ecology, even though the regions are close to one another. ${ }^{3}$ But further, van Vollehoven did not show the difference in detail in the characteristics of the diversity of the customary law community of Papua. From the identification of 19 areas of customary law communities as an integrated whole in accordance with their respective cultural and customary laws as customary law requirements. This means that customary law institutions as a guideline in the effort to maintain life as an ideal in various dimensions of the social life of the indigenous peoples concerned. Customary law institutions are systems and / or original rules that have long been guided by the customary law community as a means of social control. In customary law institutions, the status of the rights and obligations of customary law communities has traditionally been handed down through generations and is inherited based on the structure and social organization of indigenous and tribal peoples as reflected in the diversity of Papuan customary law communities based on geography and cultural ecology.

Recognition of the rights of indigenous and tribal peoples over land and natural resources in Indonesia, is very much related to the provisions of Article 18B paragraph (2) of the 1945 Constitution of the Republic of Indonesia (1945 Constitution) which stipulates that "the State recognizes and respects unity - the unit of customary law communities and their traditional rights as long as they are still alive and in accordance with the development of the community and the principles of the Unitary State of the Republic of Indonesia, which is regulated in law ". These provisions provide a constitutional position for indigenous and tribal peoples in relation to the state and a constitutional basis for state administrators, how indigenous and tribal peoples should be treated, as well as constitutional mandates that must be obeyed by state administrators, to regulate the recognition and respect for the existence of indigenous and tribal peoples in a form Constitution.

Land has an important function in human life. aware of this, the need for state intervention to help regulate it. Article 33 Paragraph (3) of the 1945 Constitution of the Republic of Indonesia, states that "the earth, water and natural resources contained therein are controlled by the state and used as much as possible for the

\footnotetext{
${ }^{1}$ Allot, Anthony \& Gordon R. Woodman, Ibid, 1985.

${ }^{2}$ Sulistyowati Irianto, Kesejahteraan Sosial Dalam Sudut Pandang Pluralisme Hukum, in T.O. Ihromi Antropologi Hukum Sebuah Bunga Rampai, Yayasan Obor Indonesia, Jakarta, 1993, pp. 241-242.

${ }^{3}$ Van Vollenhoven, in Soepomo, 2003, pp. 60-61.
} 
prosperity of the people". This article clearly regulates the relationship between the state and the earth, water and natural resources contained therein controlled by the state, with the aim of prospering its people. As a follow up to the provisions of this article, Law Number 5 of 1960 concerning Fundamental Agrarian Law (UUPA) was issued. Article 1 paragraph (1) of the UUPA stipulates that "the entire territory of Indonesia is the unity of the motherland of all the people of Indonesia united as the Indonesian nation. Based on these provisions, land in all regions of Indonesia is a common right of the Indonesian Nation and is eternal, that is, like the customary rights of the customary law community. Furthermore, certain pieces of land can be given to certain people and legal entities. $^{1}$

Based on the founding of the LoGA, that in order to achieve what is stipulated in Article 33 paragraph 3 of the 1945 Constitution of the Republic of Indonesia, Article 2 paragraph (2) UUPA authorizes the state as an organization of power for all Indonesian people, to the highest level be given the authority to regulate and carry out the designation, use, supply and maintenance of earth, water and space; determine and regulate legal relations between people and earth, water and space; determine and regulate legal relations between people and legal actions concerning earth, water and space. The authority of the state is exercised by the state organs, namely government agencies from the central to the regions, while the nature and authority are merely public. Furthermore, Article 2 paragraph (4) of the UUPA stipulates that "the controlling right of the said state above can be authorized to self-sufficient regions and customary law communities, only as necessary and not in conflict with national interests, according to the provisions of government regulations". These provisions relate to the administration of regional government. The granting of authority in question is an effort to advance the welfare of the people in the area concerned.

Article 3 of the UUPA stipulates that "in view of the provisions in Articles 1 and 2, the exercise of customary rights and similar rights of indigenous peoples must be such that they are in accordance with national and state interests, which are based on national unity and must not conflict with higher laws and regulations". It is clear that customary rights are recognized with certain restrictions, namely regarding their existence and implementation. Juridically, customary rights are inherent rights as a specific competence in the customary law community, in the form of authority / authority to manage and regulate the land and its contents, with the ability to act in and out of the customary law community. These special characteristics, such as non-transferability or flat development, make customary rights a special right.

Article 2 paragraph (2) PMNA / KBPN Number 5 of 1999 stipulates that the customary rights of customary communities are considered to still exist if there is a group of people who still feel bound by their customary legal arrangements as joint citizens of a certain legal alliance, which recognizes and applies the provisions the alliance in their daily lives; there is a certain customary land which is the environment of the members of the legal community and the place to take their daily needs, and there is a customary legal order regarding the management, control and use of customary land that is applicable and adhered to by the members of the legal community. The criteria and determination of the existence or absence of customary rights consist of three elements: the existence of customary law communities, the existence of customary rights, and the existence of customary legal arrangements regarding the administration, control and use of customary land that is applicable and adhered to by the customary law community. Research and determination of the existence of customary rights are carried out by local governments by involving customary law experts, customary law communities in the area concerned, Non-Governmental Organizations and agencies that manage natural resources. The existence of the customary community's remaining customary land is stated in the basic map of land registration by affixing a cartographic sign and, if possible, drawing the boundaries and recording it in the land register.

In the diversity of indigenous and tribal peoples in Papua recognize seven traditional territories, namely: 1) La Pago, 2) Mee Pago, 3) Annim Ha, 4) Saireri, and 5) Tabi / Mamta, are in Papua province, while 6) Bomberai, and 7) Domberai) is in the province of West Papua. In the seven traditional territories there are also four (4) typologies of traditional political leadership systems that are identical to the customary government system: 1) Big Man leadership system (authoritative man), 2) Klen / Ondoafi / Ondofolo, 3) King / Fun / Weight, and 3) Mixed / Sera / Mananwir system. For the traditional law community of Sentani Jayapura Regency with nine (9) ethnic groups who are in the customary area of Tabi/ Mamta with a traditional political leadership system called "klen or with the local term" Ondoafi / Ondofolo ".

The policy towards the implementation of the Special Autonomy of Papua in Jayapura Regency is partisanship, protection and empowerment of the basic rights of the Sentani adat law community in Jayapura Regency, as formulated in Article 43 of Law Number 21 of 2001 in the life of the nation and state. Because "what can be told and said by the Sentani indigenous law community which is a heterogeneous cultural ecological zone and social structure," which is reflected in other traditional law provisions, and has meanings which must be interpreted as a whole and integrated (holistic). So that it is further explained that understanding customary law in terms of substance and customary law community in terms of structure in the Sentani

\footnotetext{
${ }^{1}$ Arie S.Hutagalung and Markus Gunawan, 2009, p.22.
} 
customary law community in Jayapura Regency is placed on the legal culture itself. It means understanding the cultural values and norms of the "ideal" and "procedural" of the indigenous peoples of Sentani.

This is very basic if one misinterprets or understands the nature of the land of the Sentani customary law community, so cultural values and ideal and procedural norms of customary land are betrayed. This means that state law does not help further develop cultural values and ideal and procedural norms that are stored in the Sentani customary law community, including local culture and customary law. Because of the frequent internal and external conflicts of the Sentani customary law community in dealing with prolonged land disputes. For this reason, as an effort to understand the identity of the Sentani customary community as a whole in accordance with the characteristics of the local cultural ecology of traditional land disputes marked by the current situation of legal pluralism.

The customary law community of Sentani is categorized as a customary law community which adheres to the Territorial Genealogical principle; that is, customary law communities which have a division based on social structure and organization according to their territorial territories (adat territories) and blood relations (kinship legal system), historical origins among members of the adat law community itself. For example the customary legal system that lives in the Tabi/Mamta region: headed by a Haisori (Tobati Enggros) on the level of Ontofro (Nafri) or Ondofolo (Sentani)/Ondoafi (Deprapre) in the customary kinship legal system as a customary law institution that is still maintained for shows the status of traditional rights and regulatory norms on customary rights to customary land and natural resources as well as inheritance and marriage, autonomously administering the customary law community of Sentani Jayapura Regency.

A State recognizes and respect the units of the Sentani customary law community in Jayapura Regency defacto and dejure, normatively accommodated in Article 18B paragraph (1) and paragraph (2), jo. Article 28I paragraph (3) of the Constitution of the Republic of Indonesia (1945 Constitution) is then reduced to Article 399 of Law Number 23 of 2014 concerning Regional Government (Law No. 23 of 2014 / UU Pemda), in conjunction with Law No. 6 of 2014 concerning Villages as well as Government Regulation Number 43 of 2014 implementing Law 6 of 2014; and in the Article 43 paragraph (1) through paragraph (5) of Law Number 21 of 2001 concerning Special Autonomy for the Province of Papua (Law No. 21 of 2001) with Perdasuss No. 23 of 2008 concerning Customary Rights and Individual Rights of Indigenous Peoples. In the level of protection it is still limited to the recognition not of the detailed regulation in the form of legal policy as a focus that is relegated to district / city regulations, even though Perdasus No. 23 of 2008 but the implementation is very minimal. Through Law No. 21 of 2001 also regulates the basic rights of indigenous Papuans, particularly regarding "Protection of the Rights of Indigenous Peoples" in Chapter XI Article 43. If it is reduced to the indigenous peoples of Sentani Jayapura Jayapura Regency from the past until now in dealing with various cases of rights disputes Customary land rights in the customary law community of Sentani Jayapura Regency today, are always colored by various legal systems in dispute resolution. To settle land rights disputes, the Sentani customary law community is confronted with legal choices and which institutions are used in resolving land disputes.

The use of a legal pluralism approach, as an alternative method of settling disputes over customary rights over the customary community land of Sentani Jayapura Regency, which is colored by various legal systems (customary law, state law, religious law, other customs) that live interacting are faced with the background of the object customary land rights disputes and forms of settlement. Therefore, land disputes between the Sentani customary law community and local governments, the private sector, companies for the benefit of business / private development, as the parties to the dispute must choose the legal system and which institutions are appropriate for resolving disputes over customary rights over land. faced by the traditional law community of Sentani Jayapura Regency.

\section{Research Method}

The research location was in the customary area of the Tabi / Mamta of the customary law community of Sentani, Jayapura Regency, Papua Province. The reason for choosing the location was because of frequent disputes over boundaries and ownership of customary rights over the land of the legal community. The research approach used is the normative legal approach (normative juridical) and empirical legal approach (empirical juridical). Primary and secondary legal material collection techniques, observation, interviews. Analysis of legal materials is a description of the analysis with three workflows simultaneously, namely: the supply of legal materials, reduction of legal materials, and verification/conclusions.

\section{Results and Discussion}

\subsection{Approach to Legal Pluralism and Land Rights Conflict Disputes}

The approach of legal pluralism in the reality of normative and empirical law reflects the diversity of the legal system, namely: state law, customary law, religious law and other customs directly or indirectly affect the issue of customary rights to land in the life of the customary law community Sentani Jayapura Regency Papua. So the logical implication is the situation of legal and cultural pluralism is legal pluralism (between customary rules 
(customary land law) and national land law) can be the same between several rules and or different from one another. As the legal rules on land can be mutually compatible or contradictory and or each applies at the same time and place or vice versa in cases of land disputes in the Sentani customary law community. Each customary community group has customary rights to the surrounding land and is now a special feature of land rights in Jayapura District, which is highly determined by the social structure of each culture and local customary law that lives as the living law in the Sentani customary law community side by side and interact with state law on land. Some legal systems, such as state law and customary law, operate and interact on issues of land rights cases for the customary community of Jayapura Regency, making it really difficult to analyze the mechanism of ideal and procedural land dispute over land rights. Therefore, the legal pluralism approach becomes a tool or a means to find a neutral law in the settlement of customary land rights disputes, namely: 1) an ideological approach, 2) a descriptive approach, 3) a dispute case approach, 4) a historical approach, 5) Comparative approach, 6) Normative juridical approach, in positive law as the last bastion.

The six approaches can be used in cases of land rights over customary land disputes in various levels of settlement and interacting with state law and folk law in the customary law community of Sentani Jayapura Jayapura Regency which still adheres to customary law and religious law in addition to state law. Therefore, the concept of legal pluralism is also known by the customary law community of Sentani with the concept of "Three Furnaces" namely: 1) Government with state law, 2) Customary Institutions / Customary Government with customary law, 3) Religion and religious law. This means that the concept of the three stoves is identical to legal pluralism because it has each legal system, coexistence and interacts with each other in the customary law community. Of the three concepts as a whole guided by the customary law community of Sentani in resolving various customary land disputes in the customary area of Tabi / Mamta Jayapura Regency.

Various issues of customary land disputes over land and / or customary land rights in the Sentani customary community are confronted with the adoption of legal system choices, namely: state law and customary law as the living law and religious law regarding reduced land. in Article 3 and Article 5 of the Fundamental Agrarian Law (UUPA), Article 43 of Law Number 21 Year 2001 concerning Special Autonomy for the Province of Papua jo. Perdasus 23 of 2008, jo. Ministry Regulation of ATR/Head of BPN Number 10 of 2016, concerning Procedures for Establishing Communal Rights in Land of Indigenous and Tribal Communities in Certain Areas, dominates cases of customary land disputes in the customary law community of Sentani. So, the implications without regarding to other legal systems such as: customary land law, and habits agreed by the parties in handling land cases that interact with the object of dispute in the Sentani customary law community. Such circumstances indicate the existence of a situation of legal pluralism in the land sector relating to customary rights to land taking place continuously in the search for legal certainty, the benefit of law and justice. The existence of a situation of legal pluralism when each party to the dispute chooses which legal systems and institutions are used by the parties to resolve cases of land rights disputes to the maximum extent in order to provide legal certainty and a sense of justice. Therefore, the theoretical implication is that more than one legal system lives side by side and interacts with one particular object, namely land, resulting in conflicts (disputes) of parties who need the choices of the existing legal system. While the practical implications of the emergence of the recognition of indigenous Papuans in the ecological culture of the customary land rights of each of the Jayapura customary community based on the legal system of kinship and customary institutions (social structure and organization).

\subsection{State Law on Land in the Customary Law Community of Sentani Papua}

The land regulation normatively can be seen in some laws, such as Article (2), Article 28B paragraph (1) and (2), Article 28I paragraph (3) of the 1945 NRI Constitution; Article 3 and Article 5 of the Fundamental Agrarian Law (UUPA) Number 5 of 1960; Presidential Decree Number 55 of 1993; Minister of Agriculture Regulation/Head of BPN No. 5 of 1999, jo. Minister of Agriculture Regulation/Head of BPN No. 10 of 2016; 4) Land reform program and Presidential Decree Number 36 of 2005; Article 43 paragraph (1) through paragraph (5) of Law Number 21 Year 2001 and Perdasus Number 23 Year 2008, and other implementing regulations. When it is reduced to some of the regulations mentioned above, limited to the use of basic contextual references as an effort to implement them in Papua. Because the UUPA came into force in Papua (formerly West Irian) in 1971. The UUPA was enacted in 1960, three years later Papua was integrated into the Unitary State of the Republic of Indonesia on May 1, 1963. The question is whether the above mentioned rules can be carried out under conditions local Papuan indigenous people; or is it possible that the rules are only used as a "common foundation", how indigenous peoples understand these rules when there is a conflict (dispute) over land. Agrarian policy in the new order era is an ambivalent attitude from the government which refers to article 33 paragraph 3 of the 1945 Constitution. One party legally normative of the UUPA as the legal basis for land is still legally declared valid. But on the other hand agrarian policies and their application are not in accordance with the spirit of the contents of the 1960 UUPA.

Historically, the Lander Form Act was formerly known as Government Regulation (PP) No. 56 in lieu of the 1960 Act, the aim of restructuring land tenure arrangements for the benefit of small farmers, renewal in terms 
of lease agreements, profit sharing, pledges, etc. The Lander form mentions the maximum rights to the owner or control of land in Java 5 hectares and minimum 2 hectares. On June 17, 1993 a Presidential Decree (Kepres) was issued on Land Procurement for the Implementation of Development in the Public Interest. This means that as a concept it is not difficult to understand but it is not easy to define it as the interests of the whole society. While development activities for the public interest are limited to development activities owned by the government. There are several articles that state that there is compensation for land acquisition for holders of land rights, namely article 10 paragraph 2 , and article 13 regarding compensation can be in the form of: 1) money, 2) replacement land, 3) resettlement, 4) a combination of two or more forms of compensation (1), 2) and 3) and 5) other forms agreed by the parties. In another part of the Regulation of the Minister of Agrarian Affairs/Kepak BPN Number 5 of 1999 concerning Guidelines for Settlement of Customary Rights Rights of the Customary Law Community, referred to as a guideline for regions, namely autonomous regions according to Law Number 22 of 1999 which was revised by Law Number 32 years 2004, to conduct land affairs in relation to customary rights that still exist in the regions. ${ }^{1}$ Then there is the Regulation of the Minister of Agrarian Affairs / Kepak BPN Number 10 of 2016, in essence, the Procedure for Establishing Communal Rights of the Customary and Regional Law Communities, amended by Law Number 23 of 2014 (Article 399) and Law Number 21 of 2001 (Article 43), and Law Number Number 6 of 2014 (Articles 94 and 95).

The criteria for determining the existence of customary rights consist of three elements, namely 1) the existence of certain customary law communities, 2) the existence of certain customary rights which are the environment and place for taking the necessities of life of customary law communities, and 3) the existence of customary law arrangements regarding management, control and the use of customary communal land is adhered to by the customary law community. The Ministerial Regulation (Permen) mentioned above, provides space for the existence of customary rights carried out by the Regional Government (PEMDA) by involving indigenous peoples in the region, legal experts, NGOs and agencies related to natural resources. The effectiveness of the "Permen" is highly dependent on the LG's initiative to conduct research as a basis for determining the existence of customary community rights. In the development, Presidential Decree Number 36 of 2005 concerning the Function of Land Procurement for the Interest of Development has also issued pros and cons regarding compensation between the government and the community regarding land acquisition for development purposes. This Presidential Decree is identical to Presidential Decree Number 55 of 1993. From several state regulations on land, it is a legal basis for the mechanism of "structuring, controlling, ownership, management and use of land in all regions of Indonesia, including in Papua. Therefore the legal relationship between states' rules and society (as holders and implementers) is in the status of rights and obligations. Thus, the goal is a state ideology with a uniformity or generalization approach to land issues throughout Indonesia, particularly in Papua, without taking into account the diversity of geographical, cultural ecological, demographic, socio-cultural and customary laws. As a result, the application of these state regulations is vacuumed when implemented in cases of customary land rights disputes within the Sentani customary law community in Jayapura Regency, faced with a situation of legal pluralism in order to achieve legal certainty and a sense of justice lately.

\subsection{Customary Law on Land in the Customary Law Community of Sentani Papua}

The status of a land in the conception of the customary law community of Sentani Papua is very important for social, economic, political and religious life. Because on land most indigenous groups carry out life activities. Land functions to establish settlements, places of business, worship ceremonies and places where life ends. This means that the description above implies that the land has a religious value, meaning that the land has the highest value from the source of all its creations and the mastery of nature and the giver of life, while in a symbolical sense it is considered as a human being (a mother) who feeds and drinks and raises humans, hamlet and / or land spilled due to birth and death. This view is believed by the traditional law community of Sentani as a philosophical (ideological) view of life on land as a religious, social, economic, political, legal and symbolical value.

The meaning of land in economic culture, is focused on the utilization of natural resources both land, river, lake, and water (sea) within the boundaries of the ecological land area of customary rights of each customary law community group. Economic culture in question is all the efforts made in the context of fulfilling consumptive daily life. To run an economic culture, knowledge and technology are used that are reflected in the livelihood system, namely gardening (farming), raising livestock, hunting, gathering (sago cooking) and fishing and fishing. The pattern of land tenure and ownership of indigenous peoples is collective with classification based on social structure and organization, namely 1) tribal land tenure; 2) control of land by clan (keret/fam); 3) control of land by the nuclear family/batih (husband and wife) and unmarried children; and 4) control of land of more than one tribe/clan. Whereas land ownership is based on the principle of territorial genealogy (descent or due to

\footnotetext{
${ }^{1}$ Maria Soemardjono.S.W. Kebijakan Pertanahan Antara Regulasi dan Implementasi. Kompas, Yogyakarta, LAPERA. 2001.
} 
customary territorial territories) which is controlled according to patrilineal kinship principles. The nature of land tenure and ownership by the state and the indigenous Papuan people whose ethnic, cultural and customary law are different. For indigenous peoples the right to control land means not individually. Whereas for the state the essence of controlling land is the authority to regulate, as contained in article 2 paragraph 2 of the BAL. Supported by Iman Sudiyat, that the state only regulates the designation or use of land and its contents with the aim of the maximum prosperity of the customary law communities of Jayapura Regency, which is limited to the control, use and ownership of land.

Thus, the traditional law community of Sentani, Jayapura Regency, Papua, recognizes the concept of three stoves that is identical to the concept of legal pluralism, which is translated into three main elements:

1) Government $\rightarrow$ synonymous with state law and formal institutions,

2) Indigenous peoples $\rightarrow$ are identical with customary law and traditional institutions,

3) Religion $\rightarrow$ synonymous with religious law and religious institutions.

The concept is normatively guided by indigenous Papuans in resolving various conflicts (disputes), specifically land rights over customary land disputes.

\subsection{The Interaction of State Law and Customary Law on Land in the Sentani Customary Law Community of Papua}

Referring to B. Hooker, Griffiths and Sally F. Moore's opinion on legal pluralism which is marked by the choices regarding which legal systems are used by the parties to the dispute to resolve cases of customary land disputes in the customary law community. Sentani Papua. Particularly the parties choose and use state rules as well as customary and religious rules in accordance with the choices or expectations (needs) that will be obtained. In another part of the real form of interaction between state law with customary law and religious law is the conflict (dispute) of customary land rights for physical development by the Regional Government (PEMDA), Private, Entrepreneurs (HPH), Individuals with indigenous peoples. For example, various issues of conflicts (disputes) of customary land rights are expected in a pluralism situation by applying customary law, religious law and state law in the procedural level of resolution including:

1) Case of Amungme and Kamoro tribal land dispute with PT. Freeport Indonesia, LG and Private (entrepreneurs) in Timika;

2) The case of a dispute over the land rights of the Sentani Airport by the Sentani customary law community with the Ministry of Transportation and the Papua Regional Government.

3) The case of customary land disputes over the past land by Ondoafi Hanock Ebe Ohee with the Papua Regional Government up to the MA level.

All issues of land rights disputes over land are confronted with choices of the legal system that colors the dispute resolution procedures. Therefore, it often results in the emergence of different attitudes or views between the government and the customary law community of Papua as well as entrepreneurs of conflicts (disputes) of customary land rights from the government side (bureaucracy).

\subsection{Social Change in Customary Land Rights of the Customary Law Community of Sentani, Jayapura Regency}

The traditional law community of Sentani Jayapura Regency, in contact with the outside world through religious channels, trade, physical and non-physical development by the government, caused social changes in the form of acculturation and diffuse. Social changes related to land issues are apparent in the life of the Sentani customary law community.

1) Pattern or form of ownership or control over customary land.

The pattern of ownership or control over customary land which used to be more communal in nature, nowadays has led to individual ownership or control according to the LoGA, "Ondoafi" and/or "khoselo" which are usually as community protectors, distributors of use rights over "yo village land" khani "and or klen land "khoselo khani"now there are those who sell land on their own behalf and for their own interests. People who used to only have the right to use the land, according to the times, could have handed over to a third party. According to the Customary Inheritance Law of Sentani, a widow is not an heir to the land of the deceased over the land of her deceased husband, causing in-laws (her husband's deceased relatives) to regain land or transfer (sell) to others.

2) Land of social value becomes economic value.

Changes in the value of land due to physical development both by the government and the private sector who need land as a development space. In addition, the increase in the number of residents in Jayapura Regency automatically requires land for housing and / or private businesses such as kiosks, food stalls, workshops and so on. The collective ownership or control of customary land in Sentani leads to individual ownership or control coupled with 
high economic value land, causing large-scale large-scale land sales especially in the periphery and / or in urban areas. The alienation of customary land rights often overlaps (double certified), unclear land boundaries (intersecting). This situation has led to disputes over land between the seller and the buyer and between the buyer and buyer because of the seller.

3) Kinship relations that seem to be drifting apart

Kinship is not just greeting, visiting but more than that, one of them is the distribution of sustenance on land sales. The money from the sale of the land is distributed at least considering the relatives of the land seller. The relatives include: brothers (women and men), uncles, signs, grandfather, brother and sister of the father, nephew and others. The money from the sale of land is sometimes distributed unevenly and fairly. Family members who do not get their share sometimes blackmail, even threaten the buyer, or sell the land again on the neighboring land or the same land to a third party. Such actions have led to disputes over customary land.

4) The differences in perception between indigenous and tribal peoples and government The people of Papua in general, especially the customary law community (MHA) have not been in contact with external influences (foreign) do not know the concept of buying and selling. They only know grants and rent for land. The Dutch East Indies government understood this situation, so it leased, customary community lands for the benefit of the government. Therefore, when the Dutch East Indies government came to an end, the Papuan people in general, especially the Sentani people, held that the former leased land had returned to traditional land. The Indonesian government adheres to the teachings of International Law on State Succession, that if there is a replacement of the state, then the rights and obligations of the old state shift to the new state. Thus the lands that were used by the Dutch government for the needs of the government themselves to the Government of Indonesia. This difference in perception leads to frequent disputes between the Sentani customary law communityMasyarakat Hukum Adat Sentani (MHAS) and the government, which is always won by the government. Thus the more dominant factors in the background of disputes over customary land are: Changes in land status from social values to economic values, thus affecting the social structure and organization of the indigenous peoples of Sentani.

\subsection{Customary Land as Source of Customary Land Rights Dispute (due to historical origin)}

Customary land as a source of dispute can be allowed from a variety of normative and empirical legal materials and the results of observations and interviews indicate that the life of the Sentani customary law community over traditional lands first." In general, it is magical religious or partistpant cosmos, meaning the balance of the relationship between people and God, each other and with the natural surroundings. The balance is strictly maintained through traditional religious ceremonies and traditional parties, which are still performed by the two Sentani people. The balance of life that is participant in the atmosphere, the form of Sentani society is communal society" and the form of customary government is also adjusted to the atmosphere of life which emphasizes power over the land and all of nature above it. But after people entered the late 1970s (now) the life atmosphere of MHA Sentani mentioned above has undergone a change (acculturation process), thus affecting the structure of the socio-economic economy, especially the structure of the customary legal system of land for their lives, which refers to the principles of kinship. Land that used to have a social value in the form of shared ownership and ownership (communal rights) among the clans of the Sentani people, experienced a change to economic value, so that the form and ownership were individuals among the families of the batih.

Changes in the status of land values from social to economic are very influential on the lifestyle or behavior of the Sentani customary law community in dealing with changes in land values. This can be proven by cases of disputes over customary land, which enter Jayapura District Court. Besides that, the change in land value also affects the position of Ondoafi (ondofolo) in terms of being a customary rights holder (adat) or and for the head of the clan (khoselo) who holds land ownership rights (see dispute cases).

Land parceling occurs between the families of the batih family clans without regard to the social institutions, the intervention of buying and selling individual land that was previously unknown, which is known only as a service (marriage / service), land inheritance in male firstborn, now to whom alone without regard to the principles of kinship (genealogical). And this situation is very much felt in the life of Sentani people. When related to the situation of legal pluralism where the influence of customary land is caused by different legal orientations between customary law and state law, as well as differences in social institutions between the older generations of young people about customary land so that competition occurs between those who control customary land individually.

Following the explanation above shows that the cases of customary land disputes that have recently arisen

\footnotetext{
${ }^{1}$ Around the 1950 s until the mid-1970s also in the 1980s and 1990s.
} 
in the development of the life of the Sentani customary law community are "a shift in the value of land from social value to economic value" so that it affects the social economic structure of MHA Sentani. Besides that, based on secondary data, there are also several factors that cause customary land disputes in MHA Sentani, Jayapura Regency:

a. Historical factors (origin, genealogical, territorial);

b. Spatial system of kinship;

c. Land contracting factor during the Dutch government;

d. Leadership factors (leadership regeneration);

e. Violation (intervention) of customary rights boundaries (unclear customary rights boundaries);

f. Shifting land values from social values to economic values;

g. Compensation (distribution of proceeds from the sale of land);

h. Overlapping of land sales;

i. Situation of legal pluralism;

j. Acculturation process; and

k. Differences in the perception of indigenous peoples with the government / bureaucracy regarding customary rights and communal rights to customary community land.

\subsection{Sentani Indigenous People's Land Ownership System Based on Social Infrastructure.}

The system of land ownership or control of the customary community land of Sentani Jayapura Regency has close links with the Sentani Traditional Government system. Basically, those who have the right to control, ownership and use of land are "Ondoafi" and "Khoselo". Children "(people) do not own land only use land only (have usage rights) in terms of land management aspects, in principle the use of land is communal but there are certain provisions of this customary law according to the times, their use has led to individual ownership (individual). Below will be stated a little about the types of land found in every village in the Sentani tribal area, which at the same time will see the rights inherent in it.

1) Land owned by the village "yo kla" or "yo khani",

2) Land owned by "khani khoselo" clen,

3) Land of Services (khani memokhoi),

4) Private land (Umbai Khani).

The Sentani customary law community, knows several social institutions, such as political institutions, religious institutions, economic institutions and Sentani traditional law institutions:

3.7.1.1. Political institutions, which can only own land is Ondofolo. The method of ownership (acquiring land) owned by ondofolo is a legacy obtained from generation to generation.

3.7.1.2. Pranata Religi, that the ownership of this institutional land is ondofolo and certain people in the customary government structure. What is meant by people in the customary government structure are abu akho and khoselo. How to acquire or own land, also through war.

3.7.1.3. Pranata Ekonomi, the method of ownership here, ondofolo as the highest top holder then distributes the land to the khoselo, and through the khoselo the land is regulated for use by all members of the community. How to obtain land according to this institution is a grant. The method and form of land ownership are the same as political and religious institutions.

3.7.1.4. Customary law institutions, which land owner are only ondofolo, but for the needs of all members of the community the land is distributed to khoselo and subsequently to its citizens (agha peagha). The way to own the land was originally through tribal warfare, which was then passed down by ondofolo passed down from generation to generation.

Thus the system of land ownership can be characterized through (1) war activities (intervention) and seizure, (2) traditional ceremonial activities; (3) residence and (4) due to inheritance of land. But all of them have experienced changes, for example: the way of land ownership through war or seizure.

\subsection{The Control and Ownership of Indigenous Peoples' Land in Jayapura Regency}

There are several patterns or forms of ownership and ownership of customary / ulayat land in the Sentani adat law community in Jayapura Regency as follows:

1) Inherited land,

2) Land resulting from occupation and / or war (seizure),

3) Land that is controlled or owned with "pulo" magic,

4) Land a gift for good service, 
5) Land owned or owned because of marriage,

6) Land acquired due to fines.

The process of land ownership through several ways:

(1) through the Territorial genealogical system through kinship systems;

(2) through settlement;

(3) through warfare and the victorious party can occupy the customary land owned by the loser;

(4) Means of land grabbing or intervention;

(5) through granting due to marital relations, friendly relations because it helps others in winning all tribal wars (war aids)

(6) because it is based on a joint deliberation between several clans to determine the boundaries of the respective clan's territory, usually by territorial genealogical means.

The similarity of arrangements for the control and ownership of land rights carried out by large chiefs (large Ondoafi). Ondoafi has the position as the holder of the general authority of customary government. Because Ondoafi has a large social responsibility for its citizens (the customary law community of Sentani).

\subsection{Factors Affecting the Sentani Customary Law Community Land Dispute}

The land dispute raised was a secondary legal documentation study reported by Harold A.D. Monim (1994) in a research report affecting the emergence of customary land disputes in the Sentani adat law community in Jayapura Regency as follows:

1) Customary Land Dispute Due to History (history of origin),

2) Customary Land Dispute Due to Leadership,

3) Customary Land Dispute Due to unclear Land Rights,

4) Customary Land Dispute Due to Compensation.

\subsection{Form of Settlement of Customary Land Disputes in the Sentani Customary Law Community in} Jayapura Regency

1). The emergence of Land Rights Conflict Disputes

In general, land disputes arise due to several factors, including: a) Incomplete regulations; b) Regulatory incompatibility; c) Land officials who are not responsive to the needs and the amount of land available; d) Inaccurate and incomplete data; e) Incorrect land data; f) Limited human resources tasked with resolving land disputes; g) Wrong land transaction; h) The rights applicant's act or $\mathrm{h}$ ) The existence of a settlement from another agency, resulting in overlapping authority.

2) Types of customary rights to customary land that are commonly controlled in the customary law community in Sentani

(1) traditional lands controlled by tribes;

(2) customary lands controlled by clans, clans (keret);

(3) customary lands held by individuals;

(4) customary land controlled by more than 1 to 3 tribes.

3) The inheritance system that applies according to the customary law of the Sentani customary law community is basically regulated based on the patrineal marriage system.

\subsection{Non-Formal Institutions (Non-litigation)}

3.11.1.1. Settlement of land disputes at family name / clan level

3.11.1.2. Settlement of land disputes at the village level

3.11.1.3. Dispute resolution at the yonow level (customary council).

\subsection{Formal Institutions (litigation)}

1) Settlement of disputes at the level of Formal Government Beyond Formal Justice Formal governance in this context is village and sub-district government. Formal justice in question is the District Court, High Court and Supreme Court. The village / village administration also functions as a judicial and executive body, where the village / village head is given authority as a judge, commonly called a village / adat peace judge. Village / adat peace judge has been known since the colonial period (Dutch East Indies government $=\mathrm{HB}$ ), until today, especially in rural/village communities. Dasar hukumnya adalah pasal 71 Regeeringgs Ordonantice (S. 1906-83): Article 18 of the 1945 Constitution; Article 10 Paragraph (1) of Law Number 5 Year 1979 concerning Village 
Government with its explanation. ${ }^{1}$ Article 18 of the 1945 Constitution; Article 10 Paragraph (1) of Law Number 5 Year 1979 concerning Village Government with its explanation.

Article 18 of the 1945 Constitution; Article 10 Paragraph (1) of Law Number 5 Year 1979 concerning Village Government with its explanation. The position of the village head who is both the chief executive and judge of the Village Government, it is natural that cases that cannot be resolved at the customary level are submitted to the Village Government to be resolved. At the RW level, if the parties are not satisfied with the decision of the Coordinator of the RW, then it is conveyed to the village office or Village Administration, which of course is resolved by the village head or lurah.

The above description shows that there is cooperation between the sub-district governments, Customary villages / traditional villages and even formal justice in resolving disputes in general, specifically the resolution of disputes over land (adat). Settlement of disputes at MHAS, apparently religious norms (Christian) also gave a great influence. Religious norms have a role in every dispute resolution at every level in both the Adat Village and sub-district Government systems. The main doctrines of Christianity are: Love for God (vertical relationship) and love for fellow human beings (horizontal relationship). Horizontal relations, including the issue of religious tolerance.

2) Settlement of customary land disputes at the District Court level

At the court level, customary land disputes that cannot be resolved at the village and / or village, kelurahan or subdistrict adat meetings, the dispute is processed in the District Court. Court ${ }^{2}$ as a place of dispute resolution, is not the only place of resolution. Therefore, according to the provisions of the procedural law, the judge will provide an opportunity for the parties to the dispute to conduct deliberations in a family or peaceful way (compromise) to resolve customary land disputes. But if deliberation has been reached, it turns out that each party tends to maintain their respective positions, then the dispute will be forwarded to the court so that the decision taken by the district court is not wrong. The incoming complaints are studied first, then the disputing parties are invited to attend the hearing with several witnesses from the plaintiff or the defendant to hear their testimony all the time (hours) available.

In each hearing the parties are accompanied by one or more legal advisors in each trial. After hearing all the testimonies given both in writing and orally by the disputing parties or their witnesses, the panel of judges issued a decision based on positive applicable law (Civil Procedure Law). disputes are:

The positive legal basis that is always used by district courts in resolving land

(1) Law Number 14 of 1970 (Principles of Justice Power), duties and authorities of judges; jo Law Number 48 of 2009 concerning Judicial Power;

(2) Indonesian Civil Code that regulates the rights and obligations of people:

(3) Law Number 5 of 1960 (Agrarian Principles) and their implementing regulations;

(4) Various sectoral laws relating to land. For example: Forestry Law No. 5/1967, Mining Law No. 11/1967, Law No. 2 concerning Transmigration and Law No. 4/1982 concerning the Environment; jo Law 32 of 2009 concerning Environmental Protection and Management.

Although it has been decided by the District Court (PN) the first level is usually among the parties there are those who do not accept (not satisfied). By law there are still legal remedies in the following stages, to a higher level of court namely Appeal to the High Court (PT). If you have not received a decision at the second level, then there is still a third stage as the Supreme Court (the last) in Indonesia, namely Cassation to the Supreme Court (MA). Here the Supreme Court will study the files on customary land disputes by the court at the lower level, whether appropriate or good. After that, the decision or decision is the execution which is usually done even though there are still parties who are lacking in the execution. In addition, the Supreme Court also often returns cases of land disputes to the indigenous community itself, for example the case of customary land disputes between Yoka and Ayapo regarding the Land of the Cenderawasih University Campus.

\footnotetext{
${ }^{1}$ Soerjono Soekanto. 1986, pg, 2-4

${ }^{2}$ The court as one of the last places (strongholds) of dispute resolution, because the Sentani people are in a situation of legal pluralism, appears from the choices of the community (Sentani) in the legal system and the available dispute resolution institutions.
} 
With the three levels of resolving customary land disputes above, it is generally pursued with a decision as follows :

3.12.1.1. settlement by peaceful means (compromise);

3.12.1.2. settlement by imposing fine (compensation)

3.12.1.3. settlement by means of violence.

\section{Conclusion}

It was concluded that the approach to legal pluralism today, arises as a legal issue coloring the conflict cases (disputes) in the field of private and public law, especially the issue of customary land rights disputes in Indonesia including the customary law community Sentani Jayapura Papua Regency, reflecting that state law regarding land reduced from Article 18B paragraph (1) and paragraph (2) and Article 28I paragraph (3) of the 1945 Constitution of the Republic of Indonesia in the Basic Agrarian Law (UUPA) and its implementing regulations, including Article 43 of Law Number 21 dominates dispute cases, without regard to other legal systems such as: customary land law, and customs agreed by the parties in handling land cases that interact with the object of the dispute. Such circumstances indicate the existence of a situation of legal pluralism in the land sector relating to customary land rights in the indigenous communities of Sentani Kabupaen Jayapura, Papua.

That the situation of the diversity of the legal system (state law, customary law, religious law, and other customs) affects the object of customary land rights disputes in the customary community of Sentani Jayapura Regency. The reasons for the choice of Sentani customary law community on the basis of: 1) a sense of social justice because of the balance values based on the kinship legal system, 2) low cost and / or even no fees, 3) the trial is determined and fast-paced, 4) a sense of collective / social justice based on "cosmic" values not individual justice. While the background of the customary land rights dispute is: a) the pattern of ownership and control of communal customary land to be individual, b) land value from social value to economic value, c) strained kinship relations, d) differences in perceptions between indigenous and tribal peoples government, e) Unclear customary land boundaries between administrative boundaries and cultural boundaries due to regional splitting, $\mathrm{f}$ ) sources of land disputes due to historical origins, land tenure systems and customary community land boundaries Sentani customary punishment is unclear level: Kampung yo kla / yo khani, land belonging to the clan / khani khoselo, service land / khani memokhoi, privately owned land / umbai khani, f) inherited land, occupied / war land, magical land, service land, marital land, fine land, g) historical land, Dutch land, land leadership, land rights for cultural customary rights to administration, land compensation. The form of dispute over customary land rights, namely 1) the concept of the legal substance of the object of the dispute, 2) the legal structure of the institution that has the function to resolve land tenure and land ownership disputes or land boundaries, 3) the mechanism or procedure in the court and other institutions that can resolve land tenure disputes, and 4) legal culture, legal substance and legal structure. Thus, the form of settlement of customary land disputes over the land of the Sentani customary community through two channels, namely: formal justice (litigation) and non formal justice (non litigation). The reality is that the indigenous law communities of Sentani are more inclined to the non-litigation mechanism according to reasons of choice of law and sense of justice.

The situation of legal pluralism occurs when each party to the dispute chooses which legal systems and institutions are used by the parties to resolve the maximum land tenure cases in order to provide a sense of justice and legal certainty. So the normative feature of legal pluralism is that more than one legal system lives side by side and interacts with one particular object, namely land, resulting in conflicts (disputes) of parties who need the choices of the existing legal system. While the empirical implications of the emergence of recognition of indigenous Papuans in the cultural ecology of customary land rights of each Sentani customary law community based on social structure and organization, namely kinship law.

\section{Bibliography}

Adamson Hoebel. E, The Law of Primitive Man a Study in Comparative Legal Dynamic, Harvard University, Press 1961.

Allot, Anthony \& Gordon R. Woodman, “Introduction”, dalam People's Law and State Law, Anthony \& Gordon R. Woodman (eds). Dordrect-Holland : Foris Publications, 1985.

Harold A.D. Monim. (1994), (dalam Frans Reumi 1995), Sengketa Tanah Adat Pada Masyarakat Adat Sentani. Kerjasama Perguruan Tinggi Se-Indonesia Timur, Jayapura, LEMLIT, Uncen, Tahun 1995.

Hilman Hadikusuma, Pengantar Antropologi Hukum, Bandung, PT. Citra Aditya Bakti, 1992.

John Griffith, “What is Legal Pluralism”, Journal of Legal Pluralism, 1986.

Jaka Soehendra. Mengalternatifkan Aturan Adat Dalam Mengatasi Masalah Pemanfaatan Sumber Daya Hutan. Contoh Kajian Dengan Menggunakan Pendekatan Pluralisme Hukum. (Paper) Upgrading of Lecturer in Anthropology of Law and Legal Sociology organized by the Faculty of Law, University of Indonesia, July 18-30, 1994

Laura Nader and Harry F. Tood JR, (Ed) The Disputing Process Law in Ten Societies, New York, Columbia 
University Press, 1978.

Leopold Posipisil, Anthropology of Law a Comparative Theory, Yale University, Harper and Row, Publishers, 1971.

Nader, Laura and H.F. Todd, Jr (eds) The Dispute Proces : Law in Ten Societies. New York: Columbia University Press, 1978.

Maria Soemardjono.S.W. Kebijakan Pertanahan Antara Regulasi dan Implementasi. Kompas, Yogyakarta, LAPERA. 2001.

Masinambow. E.K.M. (Ed) Hukum dan Kemajemukan Budaya (Sumbangan Karangan Untuk Ulang Tahun ke70 Prof. DR. T.O. Ihromi), Jakarta, Yayasan Obor Indonesia, 2000.

Slaats, Herman \& Karen Portier, Traditional Decision-Making and Law. Institutions and Processes in An Indonesian Context. Terutama Bagian "Introduction. Yogyakartya : Gadjah Mada University Press, 1992.

Suteksi dan Galang Taufani, Metologi Penelitian Hukum (Filsafat, Teori dan Filsafat). Rajawali Pers PT RajaGrafindo Persada Depok.

Sulistyowati Irianto, Kesejahteraan Sosial Dalam Sudut Pandang Pluralisme Hukum, dalam T.O. Ihromi Antropologi Hukum Sebuah Bunga Rampai, Jakarta, Yayasan Obor Indonesia, 1993.

Sally Falk Moore, Law as Process An Anthropology Approach, University of California, Los Angles Roudhedge and Kegan Paul, 1978.

Sihombing B.F, Evaluasi Kebijakan Pertanahan Dalam Hukum Tanah Indonesia, Jakarta, Toko Gunung Agung, 2005.

Slaats, Herman \& Karen Portier, Traditional Decision-Making and Law. Institutions and Processes in An Indonesian Context. Terutama Bagian "Introduction. Yogyakartya : Gadjah Mada University Press, 1992.

Sumardjono Maria S.W. , Kebijakan Pertanahan Antara Regulasi dan Implementasi. Yogyakarta. LAPERA, 2001.

Kebijakan Pertanahan (Antara Regulasi dan Implementasi), Jakarta, Kompas. (Edisi Revisi), 2005.

T.O. Ihromi (Penyunting), Antropologi dan Hukum, Jakarta, Yayasan Obor Indonesia, 2000. , Antropologi Hukum Sebuah Bunga Rampai, Jakarta, Yayasan Obor Indonesia, 2000.

Yando Zakaria and Djaka Soehendra, Pengaturan Hukum Adat Tanah Dalam Perundang-Undangan Nasional dan Rasa Keadilan, (Paper) at the National Seminar on Land Pluralism in Indonesia, organized by YLBHI. Jakarta, September 7, 1994.

Werner Menski, Perbandingan Hukum Dalam Konteks Global Sistem Eropa, Asia, dan Afrika (Comparative Law In Global Context). Penerbit Nusamedia, Bandung, Tahun 2012.

Perbandingan Hukum Dalam Konteks Global Sistem Eropa, Asia, dan Afrika (Comparative Law In Global Context). Nusamedia Press, Bandung, 2012, pg, 113, in Suteksi and Galang Taufani, Metodologi Penelitian Hukum....., 2018. 